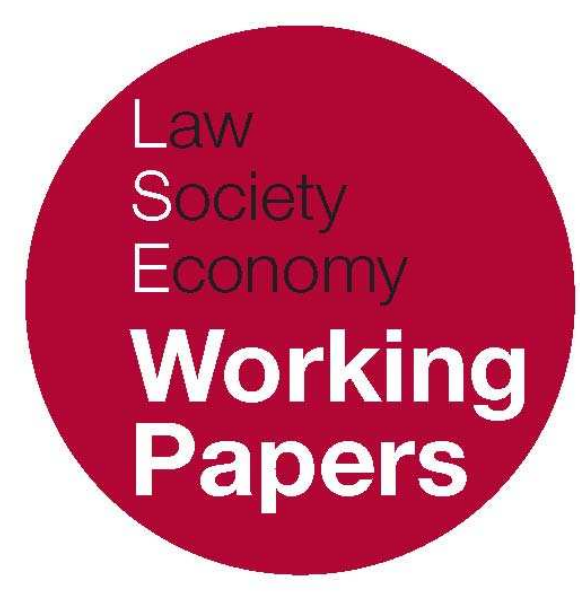

\title{
Copyright Infringement, 'Free-Riding' and the Lifeworld
}

\author{
Anne Barron \\ LSE Law, Society and Economy Working Papers 17/2008 \\ London School of Economics and Political Science \\ Law Department
}

This paper can be downloaded without charge from LSE Law, Society and Economy Working Papers at: www.lse.ac.uk/collections/law/wps/wps.htm and the Social Sciences Research Network electronic library at: http://ssrn.com/abstract=1272564.

(C) Anne Barron. Users may download and/or print one copy to facilitate their private study or for non-commercial research. Users may not engage in further distribution of this material or use it for any profit-making activities or any other form of commercial gain. 


\title{
Copyright Infringement, 'Free-Riding' and the Lifeworld
}

\author{
Anne Barron *
}

\begin{abstract}
The dominant explanatory/justificatory framework informing scholarly commentary on copyright law, policy and theory today - certainly in the US - is law and economics. From this perspective, copyright law exists to underpin markets in certain categories of information good' (copyright works). These markets in turn function to ensure that the private costs and benefits of information production and consumption line up (more or less) with the social costs and benefits of these activities, ie that 'free-riding' on the efforts of information producers is (more or less) curtailed. A widely held view is that this tradition of what might be called 'copyright-law-and-economics' is now deeply divided - between adherents to what Glynn Lunney has called 'copyright's incentives-access paradigm' on the one hand, and proponents of what Mark Lemley has called the 'full value' or 'absolute protection' paradigm on the other. Absolute protection theorists tend towards the view that all uses of copyright works should be capable of being controlled (and so priced) by the right-owner; incentivesaccess theorists distinguish between uses the control of which would affect the information producer's incentives ex ante, and those that would not, and recommend that copyright protection should extend to the former category only. This paper examines the features that are said to distinguish the two paradigms from each other, focusing especially on the approach each recommends to copyright's scope (ie the issue of what uses of copyright works properly constitute copyright infringements). Particular attention is paid to the efforts of critical economists of intellectual property law such as Lemley and Brett Frischmann to retrieve and advance versions of the incentives-access paradigm with a view to counteracting the disadvantages for society they believe are associated with the absolute protection paradigm. Ultimately, however, I conclude that too much has been made of the distinction, and that the debate over which paradigm should have priority in determining the contours of copyright policy distracts attention from a more fundamental issue - the hegemony of economic analysis generally in organising the conceptual and normative universe of legal scholars working in this area. Thus while sympathetic to the impulse underlying the efforts of Lemley and Frischmann - a concern to resist the seemingly relentless expansion of copyright towards the horizon of absolute right-holder control of all uses of copyright material - I argue that their lingering adherence to the presuppositions of economic analysis has stymied their well-meaning efforts to account for the social value of 'information' in terms distinct from the merely economic measure of price. My overall aim here is to suggest that, because of its presuppositions, economic analysis - in whatever paradigm it may be packaged - offers at best a blinkered perspective on both copyright law and the field of social life that copyright law affects. I conclude by proposing Jürgen Habermas's social theory as an alternative framework in relation to which critics of copyright expansionism might fruitfully orient themselves in the future.
\end{abstract}

* Law Department, London School of Economics. Thanks are due to participants at a workshop on the theme of 'Inspiration, Innovation, or Infringement: Multidisciplinary Perspectives on Piracy and Copyright' - convened at Emmanuel College, University of Cambridge, UK on July 1st 2008 under the auspices of the Centre for Intellectual Property and Information Law, University of Cambridge - who patiently endured a first draft of this paper. 


\section{INTRODUCTION}

A quick browse through the Social Science Research Network's repository of Intellectual Property Law articles uncovers a voluminous literature on copyright law, policy and theory. Yet despite its apparent diversity, much of this commentary is underpinned by the same unquestioned assumption: that some version of economic efficiency - the achievement of which involves balancing the social costs of activities (such as creating cultural artefacts and controlling how these are used) against the benefits of those activities - is the crucial, if not the only, criterion for evaluating both the institution of copyright and the field that it regulates. ${ }^{1}$ Commentators may have different understandings of how costs and benefits should be measured, and of how private costs and benefits can be made to match up with social costs and benefits, but the idea that a cost-benefit equation is the acid test of defensible analysis and policy in this area is rarely challenged. ${ }^{2}$ Amongst the more overtly committed of law-and-economics scholars, this general idea tends to be invoked in relation to a cluster of rather more technical categories of economic analysis, and some of these - notably the concepts of public good and externality - are particularly relevant to the project of explaining, and prescribing for, copyright law in economic terms. Very briefly, the premise of this project is that information 'goods' are often difficult and expensive to create; yet once produced, they tend towards the condition of public goods they are non-rivalrous, and relatively non-excludable. ${ }^{3}$ In so far as they remain in that condition, they are easily re-used by others apart from their originators, and it is difficult if not impossible to enforce payment for acts of re-use. The immediate result is 'free-riding': the obtaining of benefits from these goods by those who have not shared in the cost of producing them. The ultimate result is underproduction, ${ }^{4}$ because the inability to enforce payment for the use of these goods acts as a disincentive to their production in the first place.

Adherents to the framework of law-and-economics agree that the solution to this problem is to institute rights of private property in relation to these goods, although there is considerable disagreement as to how and to what extent this

\footnotetext{
${ }^{1}$ For an analysis of the concepts of economic efficiency at play in the law and economics literature generally, see N. Mercuro and S. G. Medema, Economics and the Law (Princeton, NJ: Princeton University Press, $2^{\text {nd }}$ ed, 2006) esp 20-32; 68-93.

${ }^{2}$ Wendy Gordon has recently noted that ' $[t]$ he most profitable lines of analysis for copyright ... have been drawn from economics, where the most influential writing has so far come out of the United States' (W. Gordon, 'Intellectual Property' in P. Cane and M. Tushnet (eds) The Oxford Handbook of Legal Studies (Oxford: Oxford University Press, 2003) 617-646, 624.)

3 A public good is centrally characterised by the attribute that one person's use of it does not interfere with any other person's use of it and, relatedly, that it is not exhausted by use. Public goods often, though not always, possess a second feature that distinguishes them from private goods: it is difficult to exclude those who do not pay to use them from the benefits of so doing. Frequently cited examples of such 'pure' public goods (possessing both characteristics) would include lighthouses and public defence.

${ }^{4}$ Goods are under-produced in this sense when they are not produced even though, once produced, they would be worth more to consumers than the cost of producing them.
} 
should occur. A property right is a mechanism (though not necessarily a legal mechanism ${ }^{5}$ ) by which a would-be non-payer can be denied use of the goods to which the right pertains unless the right-holder's price is paid. Instituting property rights thus enables the internalisation - within a market in valued uses of valued goods - of 'external'6 benefits formerly accruing to users.' A copyright is a legally enforceable property right that is vested in the first instance in the originator of certain categories of information good ('works'), and subsists in relation to them. A copyright thus gives to the originator exclusive legal control over certain acts in relation to the work - not acts of use as such, but only certain acts of replication and repetition (in what follows I shall use the term 'copying' to encompass both acts of replication and repetition). 'A' copyright is thus in fact a bundle of discrete rights, each relating to a different act. To be effective, the rights in the bundle must be enforced through the courts, which can either enjoin unauthorised uses or award monetary damages when infringements cannot be enjoined. The economic logic of this structure can be represented as organised around the assumption that information goods - as public goods - are exceptionally easy to replicate and to repeat. If the originator is unable to invoke a legal right to prevent the copying of his or her work, competitors have an incentive to make replications and

\footnotetext{
${ }^{5}$ For economists of property rights, the latter could simply be factual capacities to enjoy assets, as distinct from government-sanctioned privileges. Thus, '[w] here a person is capable of effectively creating exclusive control over some resource, he has the equivalent of an exclusive right, by whatever name his situation goes. Exclusivity is sufficient for simulating an exclusive right.' (E. Mackaay, 'Economic Incentives in Markets for Information and Innovation' (1990) Harvard Journal of Law and Public Policy 867, 875). See further e.g. J. Umbeck, Might Makes Rights: A Theory of the Foundation and Initial Distribution of Property Rights' (1981) 19 Economic Inquiry 38; Y. Barzel, Economic Analysis of Property Rights (Cambridge: Cambridge University Press 1989) Chapter 1.

${ }^{6}$ In general, externalities are social consequences of action - whether harmful or beneficial - that are not registered, or not fully registered, by the actor; while internalisation is a process of bringing the consequences of action to bear in some way on the actor that caused them. Welfare economists argue that the market is in general the most effective system for internalising externalities, because it subjects action consequences to a pricing mechanism that causes actors to count their monetary costs or benefits. (Moreover, where the social costs or benefits entailed by an action are priced in this way, actors are given reliable signals as to what kind of conduct to engage in and what to avoid: the market thereby deploys the price mechanism to efficiently coordinate productive activities and allocate society's scarce resources to their most valued uses.) As Wendy Gordon has pointed out, 'most of IP law is concerned with internalizing positive externalities: when someone copies or adapts a book or invention without paying the originator, the benefit remains "external" to the originator and is thus unlikely to affect her incentives. When IP [law] requires the copier or adaptor to pay, part of the benefit is 'internalized' to the originator.' Gordon, $\mathrm{n} 2$ above, 622.

${ }^{7} \mathrm{~A}$ user in this context could be one whose use of the good is merely consumptive, or one whose use involves the production of another instantiation of the good for consumption by others. In relation to the latter, something like Richard Watt's distinction between information goods and what he calls 'delivery' goods or services is useful (R. Watt, Copyright and Economic Theory (Cheltenham: Edward Elgar, 2000) 4.) A delivery good is a physical artefact (such as a book) in which information is relatively durably instantiated; a delivery service (such as a lecture) communicates information while leaving no physical trace after the delivery has been completed. Uses of information that involve conveying it to others necessarily involve embedding it in one or other of these modes of delivery. In the absence of property rights in information, its public good characteristics entail that anyone other than its originator can embed it in new delivery goods and services and sell these at a price that does not reflect the investment incurred by the originator in generating the information. This ability to undersell the originator in markets for delivery goods and services in turn enables this category of non-paying user to compete profitably with the originator in these markets.
} 
repetitions available to consumers by means, respectively, of delivery goods (e.g. books) and services (e.g. film showings) incorporating these as long as the market price for these delivery goods and services is greater than the marginal cost of producing them (e.g. the cost of printing each additional copy of a book). Consequently, the market price for these goods and services will be driven down to the marginal cost of production. However in that event, the originator of the work - or the investor who has paid for the right to produce commodities incorporating that work - will be unable to price their own delivery goods and services at a level yielding an adequate return on the investment in the work. ${ }^{8}$ (In a competitive market, the market price will be that of the lowest-cost producer, and copiers of works will face lower average production costs than investors in works, if only because copiers do not have to pay for the use of the work.) As a result, those who would have invested in works may turn to other activities that are better recompensed, even though social welfare ${ }^{9}$ would have been better served by their investing in creating and/or disseminating works.

Viewed from an economic perspective, the function of copyright law is to deal with this problem. As currently organized, it does so by vesting in the 'author'10 of a work an array of transferable ${ }^{11}$ rights to control certain acts of copying: all kinds of reproduction (including adaptation) of the work, various forms of distribution (including commercial sales and rentals, and institutionalised lending) of the work, and all kinds of public communication (including public performance and electronic transmission) of the work. These controls extend to non-literal as well as literal copies, and more generally to copies that replicate or repeat less than the whole of the work. ${ }^{12}$ The UK's Copyright, Designs and Patents Act 1988 thus provides that anyone who does any of the acts restricted to the copyright owner to the whole of a protected work, or any substantial part of it, infringes copyright in the work unless some defence or exception applies. (The most well known of the available defences in the British context are those which excuse 'fair dealing' with a work for the purposes of non-commercial research and

\footnotetext{
8 Private goods are produced efficiently when the value consumers place on the last unit of the good to be produced equals the cost of producing that unit (its marginal cost).

9 Social welfare is generally defined in the law-and-economics literature as the sum of all individual utilities. See page 7 below for an elaboration of the meaning of 'utility' in this context.

${ }^{10}$ The authors that UK law recognises as copyright owners are not simply individuals, nor is the authorial effort rewarded by the law confined to intellectual effort alone: corporate enterprises whose organisational and financial inputs yield films, sound recordings, broadcasts and publications (sometimes referred to as 'entrepreneurial' works to distinguish them from the 'authorial' literary, dramatic, musical and artistic works produced by merely intellectual investment) are also defined as authors by virtue of these inputs; and an employer who employs a human author to create an authorial work will generally be regarded as the first owner of any copyright in it: Copyright Designs and Patents Act 1988, ss 9-11.

11 In practice, of course, the copyrights in works that have commercial value generally are transferred to commercial intermediaries - eg publishers and producers of various kinds - who expect to profit from their own investment in acquiring rights to works and then embedding these in delivery goods and services which can be sold to consumers.

12 As a legal matter, a copyright work is conceived of as extending well beyond a notional 'surface' (eg the sequence of words appearing on the pages of a book) to deeper 'layers of abstraction' (including eg the plot of a novel) underlying or structuring that surface. Thus non-literal copies of a work may infringe copyright in that work.
} 
private study, criticism or review of that or another work, and news reporting.) Liability for these acts of 'primary' infringement is strict in the sense that no knowledge of any wrongdoing needs to be shown. However, the Act also imposes liability on those who have materially contributed to the doing of these acts by others or have dealt commercially with infringing copies made by others, though generally only where such contribution or dealing is accompanied by actual or constructive knowledge of the infringing act. In sum, whether copyright in a given copyright work has been infringed depends on (i) whether the statutory list of restricted acts extends to the act carried out by the alleged infringer; (ii) if so, whether that act has been done to the whole of the work or a substantial part of it; and (iii) if so, whether a defence or exception applies. Further, (iv) copyright in the work may in some circumstances be invoked to prevent not only acts of primary infringement carried out directly in relation to the work, but also further acts carried out in relation to some act of primary infringement.

Acts of copyright infringement can be re-described in economic terms as acts of free-riding ${ }^{13}$ and, as such, condemned as socially harmful as well as unlawful. The real power of the economic analysis of copyright law, however, resides in its claim to be able to judge whether any given copyright system - as a particular configuration of legally instituted property rights in information - is itself efficient. Where it is judged not to be, acts involving no infringement of copyright under the current law can nonetheless be declared harmful acts of free-riding that call for some process of internalisation. The expansion of copyright in recent years transforming activities previously deemed lawful into acts of copyright infringement that can be legally enjoined - is attributed by some commentators to the pressure exerted by precisely this kind of argument. ${ }^{14}$ The argument proceeds, it is said, from the idea that externalities amount to a market failure requiring correction, and this in turn is said to be the organizing idea of a new, but currently dominant, school of economic theorising about copyright which is quite distinct from the standard economic analysis of the institution.

According to the standard analysis - what Glynn Lunney has termed 'copyright's incentives-access paradigm'15 - an efficient regime of copyright protection is a 'balanced' regime that limits the unpaid use of information goods just enough to ensure the right level of incentive to motivate their production at a socially optimal level, but no more. The newer framework, described by Mark Lemley as an 'absolute protection' or 'full value' view of intellectual property, is said to be defined by a strong normative commitment to the internalisation of all

\footnotetext{
13 '[C]opyright is only valid against those who "free-ride", and not against fully independent creators' (Gordon, n 2 above, 630).

${ }^{14}$ See eg N.W. Netanel, 'Copyright and a Democratic Civil Society' (1996) 106 Yale Law Journal 283; M.A. Lemley, 'Property, Intellectual Property, and Free Riding' (2005) 83 Texas Law Review 1031; B.M. Frischmann, 'Evaluating the Demsetzian Trend in Copyright Law' (2007) 3:3 Review of Law and Economics 649.

15 G. S. Lunney, 'Reexamining Copyright's Incentives-Access Paradigm' (1996) 49(3) Vanderbilt Law Review 483.
} 
externalities arising from the use of information: ${ }^{16}$ it holds that legally instituted rights of private property should ideally extend to every valued use of information, such that users would be required by law to pay the owner's price for any such use except in atypical instances of unavoidable market failure. It is this view, so it is claimed, which has legitimated the steady expansion in the scope of copyright at national, regional and international levels along each of the four axes identified above: the range of acts restricted to the copyright owner has widened, the range of circumstances in which secondary liability will be found has also widened, the likelihood that courts will find partial or non-literal takings 'substantial' (and so infringing) has increased, and the reach of defences and exceptions has narrowed. Meanwhile, recent legal initiatives have given copyright owners new rights variously dubbed 'para-copyrights' or 'digital' rights - oriented towards preventing the circumvention of DRM systems applied to copyright material. DRM systems enable right-owners to physically limit access to, and regulate use or re-use of, any information (including information taking the form of a copyright work) that exists in a digitised form. These mechanisms can thus enable a kind of control that goes well beyond copyright in so far as it regulates access to and use of digitised material in general (whether protected by copyright or not) as opposed to particular acts of copying carried out in relation to copyright works. In this way, DRM permits a form of control in relation to intangible information roughly equivalent to that achieved by fences, locks or guards in relation to tangibles. Considered in relation to the absolute protection model of copyright, DRM seems a major step towards the actualisation of this model.

This paper is animated by the conviction that too much has been made of the distinction between the incentives-access and absolute protection approaches to copyright. Ultimately, my aim here is to show that these have much more in common than is generally perceived, and that the debate over which should have priority in determining the contours of copyright policy distracts attention from a more fundamental issue - the hegemony of economic analysis generally in organising the conceptual and normative universe of US-based legal scholars working in this area. That said, most of the paper is oriented towards attending to the features that are said to distinguish the absolute protection paradigm from the incentives-access paradigm, and to the efforts of critical economists of IP law such as Mark Lemley and Brett Frischmann to retrieve and advance versions of the latter with a view to counteracting the disadvantages for society they believe are associated with the former. Sections 1 and 2 below accordingly consider how 'incentives-access' and 'absolute protection' have been constructed as two distinct frameworks within the field of copyright-law-and-economics by scholars working in this field. Section 1 briefly considers the incentives-access paradigm. Section 2 considers the absolute protection paradigm, chiefly from the perspective of the critical accounts of it that Lemley and Frischmann have offered. Both of these critics are convinced of this paradigm's distinctness from the traditional

16 Lemley, n 14 above. 
incentives-access rationale for copyright. Both aim to regenerate a version of the incentives-access rationale to counteract the absolute protection approach. Both believe that the latter is largely responsible for the expansion in copyright's scope in recent years, an expansion they are concerned to reverse or at least suspend. And both appear to agree that Harold Demsetz's economic theory of property rights provides the normative foundation for the absolute protection approach.

Section 3 focuses on interrogating these critics' conception of the normative questions at stake in the 'incentives-access versus absolute protection' debate, and to this end it investigates the core premises of Demsetz's theory. What I aim to uncover here is the fundamental unity that underlies the apparent divide separating the incentives-access approach from its supposed rival. Briefly put, what the two paradigms share is a particular vision of the social order and of the nature of social interaction - a vision that animates economic theory generally, whatever its particular applications. At root, economic theory advances a model of society as constituted by individual actors whose actions are governed solely by the urge to maximise their utilities; and it conceives of social coordination as emerging from the competitive exchanges of these actors, mediated by the price mechanism in the context of a market. ${ }^{17}$ 'Utility' here is inferred from the choices market actors make in ranking their wants in order of preference and calculating how to deploy their scarce means to satisfy these preferences via market transactions. ${ }^{18}$ Utility is thus claimed to be an objective measure of satisfaction that abstracts from (what to the economist appear as) the many subjective and incommensurable ends that motivate individuals to act. It is objective, so it is said, because it refers only to what is objectively observable: the preferences revealed by market behaviour. In facilitating the satisfaction of a multitude of these 'revealed preferences' through a network of competitive exchanges mediated by price, the market is supposed to reconcile individual self-interest with social welfare mechanically, as it were, and without embedding within itself any particular conception of what is normatively (or cognitively, or aesthetically) valuable.

Yet while ostensibly only a technical design for the allocation of scarce resources, the idea of the market in economic theory is also a particular representation of social relations as competitive interactions between atomised, purposively-rational agents. Further, this idea has influenced how normative questions of all kinds - and not simply questions of efficient resource allocation are addressed in societies whose modes of social exchange are in fact dominated by the calculative strategies associated with the market. ${ }^{19}$ In particular, economic theory's privileging of choice, competition and the price mechanism reflects its positive evaluation not only of the economic functions these serve but also the

17 For an illuminating elaboration of the core premises of modern economics, see D. Slater and F. Tonkiss, Market Society: Markets and Modern Social Theory (Cambridge: Polity, 2001), Chapter 2.

18 ibid, 48. See also J. O'Neill, The Market: Ethics, Knowledge and Politics (London: Routledge, 1998) Chapter 3

${ }^{19}$ See generally J.G. Carrier, 'Introduction', in J. G. Carrier (ed.) Meanings of the Market: The Free Market in Western Culture (Oxford: Berg, 1997). 
norms they presuppose: a norm of freedom as individual liberty to rank and pursue given wants, a norm of equality that refers to the processes rather than the outcomes of this pursuit, and a norm of rationality as the calculation of the least costly means of this pursuit. The reasons why individuals want what they want are irrelevant from this perspective (economic theory does not aspire to explain how preferences are formed), as are the questions of whether and under what conditions those reasons could be intersubjectively shared: as far as economic theory is concerned, there is no dimension of meaning or value that is not reducible, in the end, to the private calculations of individuals.

When applied to the field regulated by copyright law, economic theory produces a peculiar picture of the social relations and dynamics that it finds there. From its perspective, the emanations of language and art are so many units of 'information' that can be reified as objects of property rights and allocated to 'innovators' as if created from nothing; while communicative interactions are reduced to exchange relations between producers and consumers of information goods. Moreover, the reasons why producers supply, and consumers demand, information goods are peripheral to a properly economic explanation of these behaviours. For example, the writer who churns out formulaic potboilers for no other reason than to pay her rent is indistinguishable - qua economic actor - from the journalist who seeks through her works to enrich political debate, the scholar who advances a theory in the hope of convincing others of its explanatory power, or the poet who endeavours through words to transfigure others' imaginative horizons. By the same token, the reasons motivating readers to the various forms of engagement that these works invite cannot be differentiated either. From the vantage point of economic theory, all economic actors are presumed to choose between different action possibilities with a view only to maximising their utilities. The choice of each actor is based on a ranking of preferences that must be taken by the theorist to be exogenously given: the ranking reflects only a calculation of the relative costs and benefits to the actor of satisfying them. Copyright's role here is simply to steer action involving the production of information by influencing the cost-benefit calculations engaged in by information producers. It achieves this by enabling uses of that information to be controlled and so priced, thereby also influencing the cost-benefit calculations of information consumers. The only issue dividing economists of copyright from each other is which uses should be capable of being controlled/priced by the right-owner: absolute protection theorists tend towards the view that all uses fall unto this category; incentives-access theorists distinguish between uses the control of which would affect the right-owner's calculations ex ante, and those that would not, and recommend that copyright protection should extend to the former category only.

Commentators such as Lemley and Frischmann - practitioners of law-andeconomics who are nonetheless critical of some of the latter's applications condemn the absolute protection approach to this issue. For these commentators, many uses of information that proponents of absolute protection would argue ought to be deemed infringements of copyright if the right-owner's price is not 
paid involve 'innovation spillovers' (uncompensated benefits generated by the activity of producing information) that, on efficiency (and other) grounds, should not be capable of being legally enjoined. While sympathetic to the impulse underlying this position - a concern to resist the seemingly relentless expansion of copyright towards the horizon of absolute right-holder control of all uses of copyright material - I argue that the lingering adherence of these critics to economic theory, and thus to the representations and norms that are presupposed by economic theory, has stymied their well-meaning efforts to account for the social value of 'information' in terms distinct from the merely economic measure of price. In Section 4 I consider the framework that, separately and together, they have advanced as an antidote to the absolute protection paradigm. I argue that their position - which effectively reinvents the idea of a balance between incentives and access as the key to an efficient copyright system - is in fact remarkably close to the neoclassical property rights theory of Harold Demsetz, so much so that their critique of the absolute protection paradigm becomes in the end an endorsement of the latter's core premises. I further argue that to the extent that Lemley and Frischmann try to eschew these premises while remaining wedded to law-and-economics - as when they invoke social benefits of free-riding that in principle cannot be internalised to market exchanges - their position becomes plagued by internal contradictions.

I conclude with the suggestion that Lemley's and Frischmann's attempts to break with law-and-economics are nonetheless interesting and important, because the aporias to which their approach leads reveal the incurable deficiencies of economic analysis - in whatever paradigm it may be packaged - as a comprehensive theory of copyright law.

\section{THE 'INCENTIVES-ACCESS’ PARADIGM}

This way of thinking (which has a long history within copyright discourse, even if it has not always been articulated in the technical language of modern economics ${ }^{20}$ ) is structured by the idea that copyright is itself attended by two kinds of social cost, associated with the lost access to information resources that rightowners' powers of exclusion in respect of them entail. First, copyright can equip right-owners with a degree of monopoly power in markets for delivery goods and services incorporating exact replications or repetitions of their works. The greater the number of modes of delivering a work that copyright law places within the right-owner's control, the more competitors are impeded from embedding the same work in new delivery goods and services of their own devising. This may in turn insulate right-owners from effective price competition in markets for delivery

${ }^{20}$ J. Ginsburg 'A Tale of Two Copyrights: Literary Property in Revolutionary France and America' (1990) 46 Tulane Law Review 991. 
goods and services: when would-be competitors are prevented from marketing perfect substitutes ${ }^{21}$ for authorised goods and services, supracompetitive prices ${ }^{22}$ can be charged to consumers of these. Whatever about the regressive distributional consequences of this kind of 'overpricing'23 - which welfare economics tends not to register as a social $\operatorname{cost}^{24}$ - one upshot is undeniably relevant to the assessment of aggregate social welfare: lost sales to those consumers who are unwilling or unable to pay the supracompetitive prices, but would have been willing to pay competitive prices. As far as these consumers are concerned, copyright - in the absence of perfect price discrimination ${ }^{25}$ - imposes 'deadweight loss.' To understand why this is so, it is necessary to recall that copyright works are non-rivalrous, and that because of this, the consumption of a work by 'low-paying' users at the competitive price would not be at the expense of others who valued it more - all could consume it simultaneously without interfering with each other's consumption. It follows that the exclusion of these low value users represents a permanent social loss. ${ }^{26}$

The second cost the incentives-access paradigm identifies as imposed by copyright concerns second-generation creators, as distinct from passive consumers. Copyright - the very mechanism that should stimulate the production of information goods - can itself limit their production. In particular, to the extent that copyright hinders follow-on creators from taking elements from protected works and building upon these to create new ('derivative') works, it necessarily raises the costs faced by these subsequent innovators: they must find the rightowner and negotiate and pay for licences to use these elements; and this may be impossible.

All this suggests that information markets exhibit a tension between efficiency in production and efficiency in consumption, or between dynamic and static efficiency. ${ }^{27}$ Proponents of the incentives-access model regard the challenge this presents as one of balancing the copyright system's dynamic benefits against

\footnotetext{
${ }^{21}$ Perfect substitutes are identical to the authorised goods and services in all respects that affect consumer preferences (Gordon, n 2 above, 641). Exact, and in some circumstances even inexact, copies of copyright works will fall into this category.

22 Supracompetitive prices are prices in excess of the marginal costs of delivery goods and services.

${ }^{23}$ Consumers who remain willing to purchase the work at its higher, more monopolistic price must pay more for the work than they would have had to pay in a more competitive market, and this transfers to the right-owner (as a monopoly profit or rent) resources that would otherwise have remained with them as 'consumer surplus' (the amount by which consumers benefit by being able to purchase a product for a price that is less than they are willing to pay).

24 'Assuming we value the welfare of both consumers and authors equally, this is simply a wealth transfer and is welfare-neutral. (M. J. Sag, 'Beyond Abstraction: the Law and Economics of Copyright Scope and Doctrinal Efficiency' (2006) 81 Tulane Law Review 187, 196).

25 Gordon, n 2 above, 642-3. Price discrimination involves charging different prices, reflecting different levels of willingness to pay, for the same uses.

${ }^{26} \mathrm{n} 24$ above, 196. Wendy Gordon has pointed out that the label 'deadweight loss' is inappropriately applied to lost access to works that would not have come into existence without copyright. Properly speaking, then, deadweight losses can only arise in relation to a particular work when the level of copyright protection available for it is beyond that necessary to call forth the work in the first place (W.J. Gordon, ‘Authors, Publishers and Public Goods' (2002) 36 Loyola of Los Angeles Law Review 139, 195).

27 n 24 above, 196-7.
} 
its static costs. They acknowledge that potential producers of information have an incentive to invest in production only if they can appropriate at least some of the value that users of information place on what they produce; and they recognize that if the ability to capture this value is non-existent, socially optimal levels of information production may not be achieved. Some producer controls over the copying activities of others are therefore regarded within this paradigm as necessary to incentivise the right level of production, but it is also recognized that these controls should be limited. As far as exact copying is concerned, the limit is reached where further producer control over what others may do with exact copies generates no additional incentive to create, and discourages production of new delivery goods and services costing less to produce than the price consumers would be willing to pay for them. ${ }^{28}$ As far as inexact copies of protected works are concerned, the paradigm acknowledges that the law must enable some of these to be controlled by the right-owner if the protection it provides is to be meaningful as an incentive. However it also recognizes that the more instantiations of the work in new formats the right-owner can veto, and the deeper copyright penetrates into the sub-surface of a work (reaching elements within the work that second comers may wish to use), the more the law approaches the point where the social benefit of the added incentive it provides is outweighed by the social cost of new production foregone:

Broadening the scope of copyright increases the incentive to produce works of authorship and results in a greater variety of such works. Broadening copyright's scope, however, also limits access to such works both generally, by increasing their price, and specifically, by limiting the material that others can use to create additional works. Given these competing considerations, defining copyright's proper scope [within this paradigm, is] a matter of balancing the benefits of broader protection, in the form of increased incentive to produce such works, against its costs, in the form of lost access to such works. ${ }^{29}$

\footnotetext{
${ }^{28}$ An example of a limit recognised in copyright law is the exhaustion doctrine, which restricts copyright owners to controlling the first entry onto the market of delivery goods incorporating copies of their works: subsequent sales of these goods cannot be controlled.

${ }^{29} \mathrm{n} 15$ above 485. Lunney's fundamental criticism of the incentives-access paradigm is that there are other social costs associated with copyright that tend to be obscured by its focus on the cost of lost access. These would include those associated with administering, enforcing and transacting over copyrights, but Lunney is particularly concerned with the lost value society would have placed on alternative productive endeavours towards which resources might have been directed had they not been lured by the incentive of a copyright into the production of copyrightable works. Yet situated as he is, squarely within the law-and-economics movement, Lunney eschews the incentives-access paradigm only to reinforce the importance of a more basic economic measure of copyright's costs and benefits allocative efficiency - as the true criterion of its proper scope. Allocative efficiency has been defined by Mercuro and Medema (n 1 above, 21) as dependent on '(i) the extent to which the allocation of inputs within the productive process results in the production of the combination of outputs that best satisfies the economic wants and desires of the individuals in society and (ii) the extent to which the allocation of these outputs across individuals in society generates the highest possible level of social well-being.' According to Lunney, ' $\mathrm{f}] \mathrm{rom}$ an allocative-efficiency perspective, copyright provides the proper degree of protection when it ensures that individuals will produce works of authorship if, and only if, such
} 
At a very general theoretical level, the difference between the absolute protection and incentives-access models is that while the latter identifies the lost free access associated with a copyright system as a cost of the system, and only measures the benefits accruing from the degree to which the system incentivises the initial creation of information goods, the former sees free access (i.e. access unimpeded by others' property rights) to these goods as itself imposing social costs, and emphasises additional benefits of the copyright system not registered by the incentives-access model: copyright's incentivisation of efficient use and development of information goods after they have been created. Consequently, each model produces a different answer to the cost-benefit calculation that is the hallmark of any economic analysis of copyright law. More particularly, each produces a different answer to the question of what activities should be regarded as infringing the copyright in any given work. Since the incentives-access model puts a positive value on free access to a work, it considers the erosion of this freedom as a cost associated with any expansion in the scope of copyright in it; meanwhile, it only registers as a benefit to be weighed against this cost any increase the expansion will bring to the incentives available for the production of works of that kind. This, then, is an approach that looks with suspicion at claims for broad copyrights, both where these claims are advanced in individual cases (when the issues are whether the defendant has carried out one of the acts restricted to the copyright owner to the whole or a substantial part of a work and if so, whether his/her activity is covered by an exception to copyright protection), and where they are advanced in the legislative arena (when the issues are whether new rights should be added to the copyright bundle or whether new exceptions to existing rights should be recognised). 30

Proponents of the absolute protection model, as we shall see, are troubled by none of these concerns. Simply put, their argument is that access is not in fact 'lost' as copyright expands, because as copyright expands access is organised, efficiently, through the private initiatives of right-owners and would-be users initiatives that would include not only licensing, but also other mechanisms (such

production would represent the most highly valued use of their resources' (n 15 above, 489). This will be the case, he argues, only when 'copyright ... renders[s] works of authorship neither more nor less difficult for a competitor to copy than non-work products' (ibid, 600).

${ }^{30}$ However, Lunney argues that the paradoxical character of the incentives-access balancing required by this paradigm has in fact produced a bias towards expansionism in judicial applications of it (n 15 above) The paradox is this: the more socially valuable a work is, the greater the need to incentivise its creation and the greater the need to ensure access to it. ' $\Pi$ ncentive and access will always oppose each other with exactly equal force' (ibid, 486), the former requiring a broad copyright; the latter requiring a narrow copyright. Consequently, the balancing of incentives against access offers no determinate solution to the problem of what the proper scope of copyright should be. According to Lunney, US courts have resolved this indeterminacy by 'implicitly presuming that more incentives are desirable in the absence of some unusual need for access' (ibid, 487), and this in turn has produced a paradoxical result: 'a copyright system that provides the most protection for those works that society least needs, and the least protection for those works society most needs' (ibid). 
as voluntary donations to the public domain ${ }^{31}$ ). Efficient private ordering ensures access - albeit at the right-owner's price, if any - and in so doing it also ensures that the emergent future value of works is properly managed and fully 'mined': right-owners who cannot themselves develop the potential embedded in their works (e.g. by producing derivatives of these, or re-formatting them) can nonetheless license others who are better placed to do so, thereby coordinating the investment necessary to maximise the work's value. Efficient private ordering in turn depends on the right-owner's willingness to licence and ability to engage in price discrimination. But once all this is in place, copyright can "facilitate market transactions that transfer information assets to their highest valued uses." 32

\section{THE ‘ABSOLUTE PROTECTION’ PARADIGM}

Neil Netanel offered a prescient analysis of this position as long ago as 1996, when in 'Copyright and a Democratic Civil Society'33 he problematised the expansion in copyright's length, breadth and depth that was already gathering pace in the US at that time. Netanel isolated, as one of the major factors behind this expansion, 'a blend of neoclassical and new institutional economic property theory'34 that he dubbed 'neoclassicism' and attributed to key law-and-economics scholars such as Paul Goldstein, Richard Epstein, and Frank Easterbrook. Emphasizing that this approach was conceptually distinct from the more traditional 'economic incentive' rationale for copyright, Netanel summarised its main tenets as follows:

Under the neoclassicist approach, copyright is primarily a mechanism for market facilitation, for moving existing creative works to their highest socially valued uses. Copyright can best serve this goal, neoclassicism suggests, by enabling copyright owners to realize the full profit potential for their works in the market. In maximizing their profit, neoclassicists argue, copyright owners will both rationalize the "development" of existing creative works and sell exploitation entitlements to those who are best able to satisfy public tastes. For neoclassicists, copyright enables owners to charge users for access to creative work public goods not so much to preserve author incentives as to determine what creative works are worth and thus to create a guide for resource allocation. ${ }^{35}$

\footnotetext{
31 See eg R. P. Merges, 'A New Dynamism in the Public Domain' (2004) 71 University of Chicago Law Review 183; R. P. Wagner, 'Information Wants to be Free: IP and the Mythologies of Control' (2003) 103 Columbia Law Review 995.

${ }^{32}$ W. J. Gordon and R. G. Bone, 'Copyright' in B. Bouckaert and G. Degeest, eds., Encyclopedia of Law \& Economics vol 2 (Cheltenham: Edward Elgar, 2000) 189-223, 194.

${ }^{33}$ Netanel, n 14 above.

34 ibid, 306.

35 ibid, 309.
} 
Netanel went on to explain that on the neoclassicist view, copyright will perform these functions to the extent that it approximates to an ideal property rights regime, and that neoclassicism sees such a regime as having four key characteristics. First, it is universal, which in the context of a copyright regime means that every valued use of every work covered by the regime should be included within the scope of the right-owner's rights, and that the law should allow right-owners free rein to appropriate the value of these uses by whatever means necessary, including refusals to licence and discriminatory pricing. Second, ownership of the rights made available by the regime should be concentrated in a single person so that transaction costs can be minimised in the management of the resources (works, in the copyright context) covered by it. (Of course efficient management may involve permitting others who are better placed to develop the work's potential to use it in one of the ways reserved to the right-owner; and this in turn will necessarily involve some transaction costs. However, on the neoclassicist view, concentration minimises these because would-be users can avoid having to deal with multiple owners of different rights in the same work.) Third, the rights made available by the regime should be exclusive, which in the context of the copyright regime means that they should equip the right-owner with an absolute power of veto over others' use of the work, such that users must contract with the right-owner for the uses they want and in each case pay an agreed price: only in situations where voluntary exchange is, and will remain, impossible should these rights be limited by mechanisms such as compulsory licences and copyright exceptions. Finally, rights made available by the regime should be fully transferable, such that they may be readily moved to the highest value users. ${ }^{36}$

Essentially, the ideas animating this picture of copyright as a species of property are that consumer preferences should ultimately direct investment in the production and management of works; that consumer preferences are best signalled through the market's price mechanism; and that copyright law's 'reification of claims to market potential' ${ }^{37}$ enables markets in desired uses of works to form and operate efficiently. Netanel's article identified as the crucial assumption embedded in this understanding of the institution of copyright that the institution gives to the right-owner a power, not so much over previously committed investment in information goods, as over the value accruing from these goods in the future. ${ }^{38}$ Whereas the former premise implies that the owner of copyright in a work should have sufficient control over the work to enable the initial investment in producing it to be recouped, the latter implies that the

\footnotetext{
36 ibid, 314-321.

37 ibid, 312.

${ }^{38}$ Hence Netanel cited Edmund Kitch as one of the key architects of the absolute protection approach to IPRs, because Kitch analogised patent rights to prospecting rights in mineral-rich lands: E. W. Kitch, 'The Nature and Function of the Patent System' (1977) 20 Journal of Law and Economics 265. For another early characterisation of the absolute protection position, see J. Cohen, 'Lochner in Cyberspace: The New Economic Orthodoxy of Rights Management' (1998) 97 Michigan Law Review 462.
} 
copyright should be broad enough to enable appropriation of the emergent value of the work over time. This conception of what is at stake in the shift within the economic analysis of copyright law - from traditional incentive theory to the newer property rights paradigm - has also been advanced more recently, in a sustained way over numerous articles, by Mark Lemley. A consistent theme of Lemley's work in this area has been that the newer paradigm recommends the elimination of all free-riding on (or the internalisation of all positive externalities generated by) intellectual creations as an end in itself, but that this position is inconsistent with the realisation of an efficient copyright system, for three reasons: '(1) there is no need to fully internalize benefits in intellectual property; (2) efforts to capture positive externalities may actually reduce them, leaving everyone worse off; and (3) the effort to capture such externalities invites rent-seeking. 39

Most (though not all) of Lemley's work on this theme is firmly situated within the discipline of law-and-economics: it is best described as an internal critique of one application of $L \& E$ by a committed practitioner of $L \& E$. In this work Lemley's essential point is that the absolute protection paradigm cannot deliver an efficient intellectual property system: that it fails as an economic analysis of intellectual property law rather than because it is an economic analysis of intellectual property law. He distinguishes between two variants of what he calls the 'ex post' justification for very broad intellectual property rights (ex post because it focuses on how IPRs incentivise the management or control of works that have already been created):

One form ... argues that intellectual property protection is necessary to encourage the intellectual property owner to make some further investment in the improvement, maintenance, or commercialization of the product. Another strand argues that such protection is necessary to prevent a sort of "tragedy of the commons" in which the new idea will be overused. ${ }^{40}$

The key to the appeal of both variants, he argues, is the too-easy analogy between intellectual property and tangible property on which each depends. ${ }^{41}$ The first variant analogises IPRs to ownership rights in respect of tangible things, but suggests that rights in intellectual creations should be such as to enable all the social benefits generated by these creations to be internalised, even though neither the economic theory nor the law of tangible property sanctions this in relation to tangibles. The second variant analogises intellectual creations to tangible things and suggests that IPRs are necessary to prevent their overuse, even though intellectual creations - unlike tangible things - are inexhaustible: the intellectual commons is not subject to the tragedy that afflicts open-access tangible resources, because information cannot be depleted by overuse. Lemley insists that although

${ }^{39}$ Lemley, n 14 above, 1032.

40 M. A. Lemley, 'Ex Ante versus Ex Post Justifications for Intellectual Property' (2004) 71 University of Chicago Law Review 129, 130.

${ }^{41}$ Lemley, n 14 above. 
the resources invested in producing information goods are indeed finite, the waste of these resources is guarded against by giving producers a limited right of exclusion, adequate to 'permit [them] to make enough money to cover their costs, including a reasonable return on fixed-cost investment' 42 but no more. It follows, in his view, that absolute protection would impose unnecessary social costs for no additional social benefits: the full value idea, in other words, fails to connect the right to capture this value to the social benefit of having intellectual property rights in the first place, which is that of incentivising the production of information. ${ }^{43}$

Internalization of positive externalities is not necessary at all unless efficient use of the property requires a significant investment that cannot be recouped another way. And even then, economic theory properly requires not the complete internalization of positive externalities but only the capture of returns sufficient to recoup the investment. Only where there is a tragedy of the commons do we insist on complete or relatively complete internalization of externalities. ${ }^{44}$

For Lemley, then, overbroad rights simply transfer wealth from users to rightowners for no good economic reason. They impose added costs on society in the form of deadweight losses for consumers, impediments to follow-on creation, the waste associated with rent-seeking, the administrative costs associated with enforcing IPRs, and the costs to society arising from over-investment in activities likely to attract IPRs. ${ }^{45}$ Their supposed benefits depend on the assumption that these rights will indeed be efficiently managed by their owners. However this assumption is unwarranted: there is no guarantee that those who happen to be designated in law as right-owners will in fact appreciate the value of the works they control and act effectively to exploit this value; and there are several reasons to doubt that efficient licensing will solve this problem. ${ }^{46}$ In this connection, Lemley notes that despite its ostensible privileging of the market as a resource allocation mechanism, the 'ex post' justification for very broad IPRs is in fact profoundly anti-market in that it favours central (albeit private) control rather than free competition: 'the ex post justifications, in other words, seem to depend on private ordering without relying on market ordering. ${ }^{2} 47$

The above summary of Lemley's position is drawn from a series of articles in

42 ibid..

43 ibid, 1057.

44 ibid, 1050-1.

45 ibid, 1058-1064.

46 M. A. Lemley, 'The Economics of Improvement in Intellectual Property Law' (1997) 75 Texas Law Review 989: 'Problems of imperfect information, transaction costs, strategic behavior, and market power [which may incentivise the right-owner to refuse to deal with market actors that might compete with it] all impose barriers to the hypothetical efficient license' (ibid, 1048-72). See also M.A. Lemley, 'Romantic Authorship and the Rhetoric of Property' (1997) 75 Texas Law Review 873, 903 and B. M. Frischmann and M. A. Lemley, 'Spillovers' (2007) Columbia Law Review 257, 277-278.

${ }^{47}$ n 40 above, 148. 
which he makes no distinction between copyright and other areas of intellectual property law whose purpose is the furtherance of innovation. However his sometime co-author, Brett Frischmann, has pursued similar themes in the particular context of copyright law - arguing, indeed, that 'copyright ... is the intellectual property system that ought to be the least private-property-like.' ${ }^{48} \mathrm{In}$ 'Evaluating the Demsetzian Trend in Copyright Law' Frischmann insists (echoing Lemley) that '[c]opyright is a system that is designed to both internalize and to promote externalities. ${ }^{49}$ Externalities, he argues, 'do not necessarily distort incentives, or more generally, the market allocation of resources: ${ }^{50}$ externalities are ubiquitous in society, and many externalities are in fact irrelevant to decisions about whether or not to invest in the activities that led to their production. Consequently, intervention to eliminate irrelevant externalities cannot be justified on efficiency grounds; and externalities to the copyright system that do not undermine incentives to invest in the creation, development, and dissemination of protected works are irrelevant in this sense. Copyright thus rightly promotes externalities (or free-riding) by leaving many uses of works (or elements of works) in the public domain, and by deploying 'muddy', context-specific doctrines such as fair use/dealing or substantiality to determine whether works have been unlawfully copied.

It is not clear from Frischmann's analysis where the dividing line is to be drawn between incentive-relevant and incentive-irrelevant externalities: the most he will grant is that both externalities and property rights have the potential to distort the market's allocation of resources, which Frischmann seems at this point in his argument to acknowledge as the benchmark of a socially optimal allocation. ${ }^{51}$ Externalities have this potential where they are indeed incentiverelevant; property rights however also have this potential because instituting them may involve government intervention where a more welfare-enhancing private solution to a genuine free-riding problem might have been found. As for the neoclassical argument that propertisation is nonetheless to be favoured because efficient licensing will ensure use of propertised information goods at socially optimal levels, Frischmann's position is that this is implausible. His reasoning here is particularly interesting, however, because it marks the point in his text where he acknowledges the limits of economic analysis - that is, he recognises the need to supplement economic analysis with alternative forms of analysis if sense is to be made of the institution of copyright. Frischmann's central argument in this connection is that 'purchasers'/licensees' willingness to pay for access and use rights will not adequately reflect social demand in market transactions. ${ }^{52}$ Such a deficit will occur when a purchaser/licensee uses a work as an input to 'socially

\footnotetext{
${ }^{48}$ Frischmann, n 14 above, 653.

49 ibid.

50 ibid, 663 .

51 ibid. Subsequently, however, he contends that 'the market may fail to allocate resources efficiently in cases where consumers' willingness to pay understates societal demand' (ibid, 665).

52 ibid, emphasis added.
} 
valued productive activities: ${ }^{53}$ Frischmann cites as examples education, community development, democratic discourse and political participation. Willingness to pay reflects only private demand - the value the purchaser or licensee expects to realize from the use - and so takes no account of the wider 'social' demand or value that others apart from the purchaser/licensee might realize from the use. Given this gap between private and social value, the institution of copyright should be designed so as to leave such uses in the public domain.

From these observations about both the supply and demand sides of the market for copyright-protected information, Frischmann concludes that

(1) externalities do not necessarily or generally distort the allocation of resources by the market; (2) the market may fail to allocate resources efficiently in cases where consumers' willingness to pay understates societal demand; and (3) ... even where externalities distort market allocation, such distortions may be social welfare enhancing. ${ }^{54}$

Pausing there, it would appear that although ostensibly engaged in a similar project to Lemley's internal (law-and-economics) critique of the absolute protection paradigm, Frischmann in fact moves beyond Lemley's pro-market position here, and indeed beyond economic analysis itself. On the one hand, the category of the 'incentive-irrelevant externality' implies that there are forms of social action that are not (or not completely) motivated by monetary incentives. Authorial production, Frischmann implies, falls into this category of action that benefits others, but is performed without the expectation of remuneration from (all of) those others: authors will continue to 'supply' regardless of whether they are able to capture the full social value of their products (i.e. extract payment for all the ways in which their creations inform, teach and engage audiences). On the other hand, Frischmann also acknowledges that social 'demand' for these uses can never be reflected adequately in market transactions between right-holders and purchasers/licensees of use rights. In short, Frischmann - albeit hesitantly and equivocally - seems to recognise that both the production and use of 'information' serve social objectives that are not reflected in market behaviour; and, in particular, that communicative exchange between authors and audiences could never be reducible to market exchange. However he offers no alternative theoretical framework that could account for the non-market dimension of copyright law otherwise than in terms of the categories invoked to account for its market dimension: supply, demand, incentive, externality and so on. Frischmann acknowledges the claim of many critics of copyright expansionism that the latter phenomenon has been bound up with 'an over-reliance on economic theory'55 in

\footnotetext{
53 ibid, 670

54 ibid, 665.

55 ibid, 661.
} 
making sense of the copyright system, and notes the insistence of these critics that copyright is more than an economic system because it implicates 'various public policies and values that are not well explained or theorized within economic theory. ${ }^{56}$ Yet he stops short of a wholesale rejection of economic theory, claiming that his own position 'fits somewhere between' 57 these critical stances and the cautious balancing of the (economic) costs of the copyright system against its (economic) benefits that is characteristic of traditional law-and-economics. Nonetheless, his qualms at least seem infectious, for in a recent article co-written with Frischmann, Lemley relinquishes his own earlier certainties about economic theory by situating himself somewhere in this middle ground alongside his coauthor. The implications of this will be explored further in Section 4 below. First, however, I examine Lemley's and Frischmann's shared debt to Harold Demsetz, a figure whose staunch attachment to economic theory has remained unquestioned over many decades, and is reaffirmed in his recent reply to Frischmann in the Review of Law and Economics. 58

\section{TWO PARADIGMS, ONE FOUNDATION}

Crucial to an understanding of both Lemley's and Frischmann's critiques of the absolute protection paradigm is an appreciation of their relation to Demsetz's theory of property rights, first advanced in an article published in 1967.59 Lemley and Frischmann each consider this article to be a canonical text in the absolute protection literature, because it fostered the notion that his economic theory of property rights could be applied in the same way to information as to land. However, as I argue below, it is impossible to attribute to Demsetz unqualified support for the total privatisation of information. In fact, Demsetz's position is far closer to that of Lemley and Frischmann than either seems willing to admit. Like them, he is committed to the view that open access arrangements for information resources can in some circumstances be efficient. ${ }^{60}$ More fundamentally, Demsetz's theories of rational action and of society are shared by Lemley and Frischmann. That is, even as they take issue with the policy prescriptions linked with the absolute protection approach to copyright, these critics retain Demsetz's commitment to the presuppositions of economic theory more generally. As we shall see, this blunts the critical edge of the conceptual tools they invoke to contest the absolute protection approach, and limits their ability to devise real

\footnotetext{
56 ibid, 662. Frischmann has in mind commentators such as Yochai Benkler, James Boyle, Julie Cohen, Terry Fisher, Lawrence Lessig and Neil Netanel, who try to combine economic analysis with other forms of theorising that account for the non-market values also served by copyright law.

57 ibid.

${ }^{58}$ H. Demsetz, 'Frischmann's View of “Toward a Theory of Property Rights" (2008) 4(1) Review of Law and Economics 127.

${ }^{59}$ H. Demsetz, 'Toward a Theory of Property Rights' (1967) 57(2) American Economic Review 347.

60 n 58 above, 130 .
} 
alternatives to that approach.

The immediate focus of Demsetz's analysis is on the emergence of private property rights in land among certain groups of indigenous people in parts of North America in the early eighteenth century, but the most abstract statement of its central thesis is as follows: "property rights develop to internalize externalities when the gains of internalization become larger than the cost of internalization.' ${ }^{61}$ Merrill offers a useful elaboration of this key point:

Demsetz hypothesized that property rights emerge when some change in the relative value of resources occurs that makes it cost-effective to internalize costs that previously were experienced as externalities.... This might be due, for example, to the introduction of new technology or the opening or closing of particular markets. Such a change in relative values causes the benefits or costs of having a property regime in a resource to change. If the change is sufficient to alter the cost-benefit equation, an alteration in the nature of property rights will take place. ${ }^{62}$

Although Demsetz mentioned intellectual property rights only in passing in his 1967 essay, he appeared there to endorse the notion that changes to their structure could be explained in the same way as changes to property rights in land. ${ }^{63}$ As far as copyright is concerned, Demsetz's analysis can therefore be taken as suggesting that an expansion in its scope might be expected to occur when new information and communications technologies raise the value of existing information goods by facilitating new means of access to and enjoyment of them, and lowering fencing and transaction costs in relation to them. This enhanced value leads to modifications in property rights ${ }^{64}$ to enable the appropriation of that value by the

\footnotetext{
${ }^{61} \mathrm{n} 59$ above, 350. As Merrill has helpfully pointed out, Demsetz actually identified three distinct kinds of externality that could be internalised by means of property rights: the external benefits that arise from investments in open access resources, the external costs that arise from dissipation of open access resources, and the external costs that arise from transacting over the use of open access resources (T. W. Merrill, 'The Demsetz Thesis and the Evolution of Property Rights' (2002) 31 Journal of Legal Studies 331). ${ }^{62}$ Merrill, ibid, 331-332. In Demsetz's own example, the causal chain is represented as follows: the growth of the fur trade in North America due to the arrival of Europeans caused the value of game in the indigenous tribes' hunting territories to rise, which caused overhunting to occur, which increased the external costs for all hunters of allowing the territories to be governed by an open access regime, which caused a system of private property rights to be introduced to take account of the economic effects made important by the fur trade ( 59 above, 352). However Demsetz made clear that if these rights emerged among the Indians of the Labrador Penninsula, and not in other regions of North America, it was not only because of the relatively higher commercial value of the fur-bearing forest animals found in this region, but because of the relatively lower cost of internalising the effects of husbanding them by means of a private property regime: forest animals confine their territories to defined tracts that can be easily demarcated.

${ }^{63}$ Towards the end of his essay, Demsetz suggests that the externality issues that arise in relation to openaccess 'ideas' are 'closely analogous to those which arise in the land ownership example' (ibid, 359), and thus can be dealt with by the same means: internalisation via property rights in 'ideas'.

${ }^{64}$ These could be achieved by means of self-help fencing measures such as encryption, social norms-based property systems, copyright reforms, legal prohibitions on the circumvention of self-help fencing measures, or all of these.
} 
creators of these resources as long as the social cost of controlling the new uses is exceeded by the social benefit of doing so.

There is no shortage of copyright-law-and-economics scholarship exhibiting a broadly Demsetzian approach to the phenomenon of copyright expansion: indeed it has become a commonplace of this scholarship that the scope of copyright has in fact expanded to enable the internalization to the copyright owner of the beneficial effects of using information goods as the value of information goods has increased and technologies and markets have emerged to make internalization seem more beneficial.65 Hence Brett Frischmann, writing from a law-andeconomics perspective, has asserted that as a method of predicting where copyright law is currently heading, the Demsetzian approach 'hardly seems controversial.' ${ }^{66}$ However Frischmann insists that Demsetz's essay has also been read by some law-and-economics scholars (whether or not Demsetz intended this reading) as carrying a strong normative message: that the continual evolution of private property rights towards a condition of complete security, absolute breadth/depth, perfect definition and full exchangeability is desirable. In an article recently co-written with Frischmann, Mark Lemley lends his support to this claim. ${ }^{67}$ The preoccupation of these scholars, then, has been with the normative thesis that - rightly or wrongly - has been attributed to Harold Demsetz, for it is this thesis that in their view legitimates the continuing expansion of copyright's scope towards the horizon of full ownership of creative works. Their concern is to contest this normative argument for enabling the private appropriation of a given work's full value, and to show why a more modest copyright regime is preferable. In Section 4 I consider how they prosecute this task.

In what remains of this Section, however, I examine Demsetz's recent clarification of what his original essay was intended to say. What this examination reveals is a quite different problem with Demsetz's analysis than that which Lemley and Frischmann find in it. The problem is not the normative thesis that these critics condemn as unsustainable, but the descriptive claims that are unreflectively advanced by Demsetz's analysis, coupled with the normative vision of society and rationality that is implied by these claims. In Section 4 it will be shown that these claims and this vision are also presupposed in the work of Lemley and Frischmann in so far as they join Demsetz in adopting the premises of

\footnotetext{
${ }^{65}$ See in particular R. P. Merges 'One Hundred Years of Solicitude' (2000) 88 California Law Review 2187 and B. Depoorter, 'The Several Lives of Mickey Mouse: The Expanding Boundaries of Intellectual Property Law' (2004) Virginia Journal of Law and Technology 1. Some of Wendy Gordon's work also fits into this category: see especially W. J. Gordon, 'Introduction' in W. J. Gordon and Richard Watt (eds.) The Economics of Copyright (Cheltenham: Edward Elgar, 2003). Gordon does not cite Demsetz here, but her account is consistent with his analysis.

${ }^{66}$ Frischmann, n 14 above, 651.

67 'Spillovers', n 46 above, 265-6. Here again, though, there is an acknowledgement that this normative 'Demsetzian' theory was not necessarily Demsetz's own position. See also n 40 above, 148 (at n74), arguing that the assumption of absolute protection theorists that information goods would not be produced at socially optimal levels unless their full social value could be captured by their producers 'is an unwarranted extension of Harold Demsetz's argument that property rights limit the creation of uncompensated externalities... . Demsetz did not argue that all externalities must be internalized.'
} 
economic theory; and that their commitment to these premises limits their ability to justify restrictions on the scope of copyright. However the first step towards clearing the way for a consideration of these issues is to dispense with the suggestion that the normative thesis Frischmann and Lemley describe as 'Demsetzian' is necessarily embedded in or implied by Demsetz's theory of property rights.

In a recent rejoinder to Frischmann's attack on 'his' normative thesis, Demsetz himself has definitively refuted this suggestion. ${ }^{68}$ In particular, he contests the reading of his article that yields this normative thesis, a reading in which private property rights figure as 'natural' results of a spontaneous evolutionary process. It is not surprising that Demsetz has distanced himself from this reading, because it is clearly impossible to argue that property rights emerge spontaneously; and indeed on Demsetz's own account they necessarily originate with a positive decision to stake a claim to a valuable resource and to back this claim with the assertion of a power to exclude, followed if necessary by practices of exclusion. Demsetz's analysis implies that, far from being natural, private property is thoroughly bound up with power and actual or potential resistance to power. ${ }^{69}$ Further, where the power to exclude is legally endorsed, the decision to endorse it is invariably itself preceded by a decision to pursue that endorsement. Again, these initiatives of claiming and granting legal rights cannot possibly be regarded as occurring 'spontaneously' (although law-and-economics scholars of all stripes certainly seem attracted to the notion that one form of law-making common law adjudication - somehow adapts legal norms 'organically' to social norms emerging spontaneously from human interaction ${ }^{70}$ ). Demsetz in his recent work makes clear that he intends to argue only that 'a cost-benefit calculus will drive legislation toward (or away from) privatization' in those areas of property law that - like copyright law - are products of legislation. ${ }^{71}$ Further, the parenthetical words in this formulation drive home his point that 'communal rights are the more efficient social arrangement under some circumstances. 72 Thus although there has been a general historical trend towards the institutionalisation of private property regimes, evidence of a contrary movement - from private property to open access - in some contexts (including that of copyright) can, he insists, be

\footnotetext{
68 n 58 above.

${ }^{69}$ Stuart Banner, 'Transitions Between Property Regimes' (2002) 31 Journal of Legal Studies 359 (powerful groups who have most to gain from introducing or extending property rights are likely to push the propertisation process forward).

70 See eg T. Palmer, 'Intellectual Property: A Non-Posnerian Law and Economics Approach' (1989) Hamline Law Review 261. Although Palmer distinguishes his position from Richard Posner's, Posner himself also privileges common law decision-making as more likely than legislation to lead to efficient regimes of intellectual property rights (W. M. Landes and R. A. Posner, The Economic Structure of Intellectual Property Law (Cambridge, MA: Harvard University Press, 2003) 417), though he adopts a very broad understanding of the 'common law' as referring 'not only to judge-created bodies of law but also to judge-created doctrines that fill gaps or resolve ambiguities in statutes or constitutions' (ibid, 417 (at $\mathrm{n}$ 25)).

71 n 58 above, 129 (emphasis added).

72 ibid, 130 .
} 
accommodated by his theory:

When the costs of preventing involuntary takings rise, as they have during the last decade in regard to computerized music downloading and computer disk copying, society shifts to greater tolerance of communal rights in the use of the involved resources, at least until cheaper methods of monitoring involuntarily arranged "takings" arise. All this is in accord with the theory of institutional change discussed in "Toward a Theory [of Property Rights]"....73

Yet despite these disavowals and clarifications, certain unproblematised assumptions are nonetheless embedded in Demsetz's analysis. The analysis implies that the taint of merely individual interest and decision that motivates the emergence and development (or not) of private property rights is ultimately negated by the social welfare gains that attend these rights (or their absence) by virtue of their origins in individual interests and decisions. As far as Demsetz is concerned, this in turn entails only uncontroversial descriptive claims: that society is constituted by private parties; ${ }^{74}$ that, collectively, these parties 'positively value efficiency ${ }^{75}$ and strive (though not necessarily consciously ${ }^{76}$ ) to maximise social welfare; that social welfare is the aggregate of individual utilities; and that the aggregation of these utilities is achieved by the market. (For Demsetz, there is no social phenomenon that lies outside the market: even that which appears as the market's outside is in truth a product of the market considered as a mechanism for achieving efficiency. 'Just as the market dictates that there will be no good $\mathrm{X}$ if the cost of producing $\mathrm{X}$ exceeds what people are willing to pay for it, so the market dictates that there will be no market if the cost of producing the market exceeds what people are willing to pay for it." 77 Thus "efficiency [can] be gained in some instances by not having markets. ${ }^{.78}$ ) Even if Demsetz is right about the purely descriptive character of these claims - and in so far as they describe an ideal market order that cannot be achieved in practice, ${ }^{79}$ they are in fact highly prescriptive in nature - they are not as modest or uncontroversial as he seems to think, for they advance an eminently contestable theory of social interaction. It is difficult to ignore the implications that arise from Demsetz's identification of the private individual as the fundamental unit of his analysis, and his singling out of efficiency - the achievement of given ends at least cost - as that which individuals 'value' (whatever particular ends they may value). The implications are that the liberty of individuals to pursue their own wants is the normative foundation of social life; that the pursuit of these wants by the most effective means is the essence of rational individual action; and that price is the necessary mechanism by

\footnotetext{
73 ibid, 131.

${ }^{74} \mathrm{n} 58$ above, 132.

75 ibid, 128.

${ }^{76} \mathrm{n} 59$ above, 350 .

77 n 58 above, 132 (emphasis added).

78 ibid, 130 (at n 3).

79 See n 17 above, Chapter 5.
} 
which individual liberties can be made compatible with social order (prices being market-generated regulatory signals that coordinate utility-maximising actions). Here the methodological individualism which is the hallmark of economic theorising shades into a utilitarian liberalism that produces a very powerful normative message indeed - albeit one that is so taken for granted by both Demsetz and his interlocutors as to escape thematisation by any of them.

\section{BEYOND DEMSETZ? COPYRIGHT INFRINGEMENT AS 'GOOD' FREE-RIDING}

Mark Lemley engages explicitly with none of these dimensions of Demsetz's thought, focusing instead on attacking the pro-propertisation thesis that he characterises as 'Demsetzian'. Yet in so far as he defends economic theory as the appropriate framework for prosecuting his case against the absolute propertisation of information, Lemley's critique of 'Demsetzianiam' is simultaneously an implied endorsement of Demsetz's social theory and his utilitarian-liberal philosophy of action. It is worth probing Lemley's position a little further here, however, because it is not always consistent. An overt defence of economic theory can be found in his 'Property, Intellectual Property and Free-Riding'. Here Lemley insists that despite its inability to give one right answer to the question of how much IP protection is socially optimal, the economic analysis of intellectual property law still offers an objectivity and a determinacy that is missing from non-economic discourses: "The fact that people can draw diametrically opposed conclusions by shifting to different nonutilitarian first principles suggests that we need some way to choose among those principles. If we have given up utilitarian economic analysis, it is not at all clear how we will make that choice.... ${ }^{80} \mathrm{He}$ appears to suggest here that the real problem with the absolute protection view of intellectual property is that it is not true economic analysis at all, however much it may borrow some of the terminology of economic theory. In fact, he implies, it is itself underpinned by a 'nonutilitarian first principle': the notion that an idealised picture of private property as absolute dominion should inform IP law, regardless of the social consequences. True economic analysis, for Lemley, can only be the traditional utilitarian project of searching for the right balance between proprietorial control and free public access, because an efficient intellectual property system depends upon finding that balance, elusive though it is. To abandon the painstaking search for that balance in favour of a default position of absolute protection (or, for that matter, an absolute public domain) is to give up on the goal of efficiency altogether. And for Lemley, it is simply not worth talking

80 Lemley, n 14 above, 1065. 
about any value other than efficiency when evaluating the intellectual property system. 81

Elsewhere, however, Lemley seems less sure about precisely this point. In a more recent article, co-written with Brett Frischmann, he appears to insist upon the limits of efficiency analysis in understanding how the use of information resources ought to be regulated. In 'Spillovers', Frischmann and Lemley argue that the market mechanism may systematically under-record 'societal demand' (as distinct from private demand measured by willingness to pay) for access to and use of - amongst other information goods - copyright works. Likening information in this respect to other intangible 'infrastructural resources' such as education, they claim that some uses of these resources may be socially desirable, and yet prevented if the attempt is made to internalise them to market exchanges underpinned by property rights. Crucially, this argument entails that property and contract cannot and should not internalise all the social benefits of using information. Acknowledging that the conventional law and economics thinking about externalities is that they are a bad thing, a market failure in need of correction, ${ }^{8} 82$ Frischmann and Lemley argue that this thinking is flawed in relation to what they call 'innovation spillovers': uncompensated benefits generated by the activity of producing information. They propose a new theory that can account for both the need to incentivise this activity and the need to make room for innovation spillovers that are good for society: infrastructure theory gives us powerful demand-side reasons for incorporating and sustaining commons within IP rights systems, and therefore for refusing to try to achieve full internalization of spillovers... IP is [best regarded as] a mixed system of private rights and commons - a semicommons - designed to generate both incentives and externalities. ${ }^{9} 83$

Yet it is not entirely clear what is new about this new theory. On one level, it can be read as a conventional economic theory of property rights - a Demsetzian theory, in fact - adjusted to account for the peculiarities of information as an inexhaustible and infinitely shareable resource. These peculiarities, Frischmann and Lemley seem to be suggesting (in a thoroughly Demsetzian vein), mean that 'even where internalizing externalities increases incentives to invest, the social costs of relying on property rights to do so still may exceed the benefits. ${ }^{3} 8$ Where this is the case, property rights in information must be 'balanced' by commons (open access) arrangements to yield the incentives-access equilibrium reminiscent of traditional copyright-law-and-economics. So far, so familiar. But at least their position is consistent when read in this way: it is recognisably, as they say, an 'economic theory ... [of] IP'85 even if not the 'alternative' economic theory they would like it to be. However another way of interpreting their argument is that

\footnotetext{
81 ibid (at n 135).

82 'Spillovers', n 46 above, 299.

83 ibid, 282.

84 ibid, 258

85 ibid, 257 (emphasis added).
} 
positive externalities arising from the use of information ought not to be internalised because society would be worse off, in some sense that cannot be grasped using a cost-benefit equation, if they were. ${ }^{86}$ This reading suggests itself where the authors discuss the socially valuable spillovers enabled by the intellectual 'commons' maintained by copyright law, comprising e.g. general ideas, facts, and excepted uses. 'Creating and consuming creative expression of different types develops human capital, educates, and socializes in a manner that benefits not only creators and consumers but also nonparticipants. ${ }^{87}$ Many exemplary excepted uses - such as fair uses for educational or critical purposes - are attended by these kinds of benefit. ${ }^{88}$ Moreover,

observing and measuring these spillover benefits is probably an impossible task. That is our point, in fact. As a society, on the whole, we recognize the value of active, widespread participation in these types of activities, and we know that creative expression is essential to participation. Thus, we encourage common access to and use of expression for these types of activities. Doing so provides a justification for a fair use doctrine based on public benefit.... ${ }^{89}$

This element of Frischmann's and Lemley's argument certainly offers a 'new way of thinking about the economics of IP' 90 but it is not a way of thinking that belongs within the realm of economic theory, and so seems out of place in the new economic theory of IP they claim to be producing. It is not only antimarket, ${ }^{91}$ but also anti-economics in so far as it suggests that 'society' as a whole has a distinct identity, distinct interests, and values that cannot be accounted for by the price mechanism..$^{92}$ Clearly, some 'nonutilitarian first principle' is being invoked here alongside (or instead of?) the principle of efficiency, though it is not at all clear which one.

\footnotetext{
${ }^{86}$ John P. Duffy also notes this conflict between Demsetz's theory and Lemley's view that there is no need to fully internalise benefits arising from the use of information of property rights: 'Demsetz's theory views external harms and benefits as always providing a potential justification (subject to cost considerations) for the extension of property rights; Lemley's theory of intellectual property posits some natural stopping point beyond which the existence of external benefits provide no justification for more property rights' (J. P. Duffy, 'Intellectual Property Isolationism and the Average Cost Thesis' (2005) 83 Texas Law Review 1077, 1077).

87 'Spillovers', n 46 above, 285

88 ibid, 288-9.

89 ibid, 289.

90 ibid, 284

91 'Even where externalities distort market allocation, those distortions may be social welfare enhancing.' (ibid, 299).

92 Thus, for example, they remark that "[t]he basic idea behind "internalizing externalities" is that if property owners are both fully encumbered with potential third-party costs and entitled to completely appropriate potential third-party benefits, their interests will align with the interests of society, and they will make efficient (social welfare-maximizing) decisions .... According to the Demsetzian theory, internalization is the silver bullet that magically aligns private and social welfare' (ibid.). In contesting this idea, Frischmann and Lemley seem to be committing themselves to the view that social welfare is not reducible to the aggregate of private utilities.
} 
Similar equivocations plague Frischmann's sole-authored 'Evaluating the Demsetzian Trend in Copyright Law', considered in Section 2 above. Again, it is not ultimately clear what the basis of Frischmann's argument is here. He could be making the (straightforwardly Demsetzian) point that balancing incentives and access within the copyright system is appropriate because the 'ancillary' social value $^{93}$ generated by using works for purposes related to education, community development, democratic discourse, political participation and the like cannot realistically be internalised due to 'collective action problems, imperfect information, transaction costs, and the diffuseness of [its] distribution. ${ }^{94}$ In other words, he could be saying that subjecting these uses to rights of private property would be inefficient, because any incentive-relevant gains achieved by subjecting them to the price mechanism would be outweighed by the cost of internalisation. ${ }^{95}$ Yet he seems also to regard these kinds of uses as posing a problem that cannot be addressed in the language of economic analysis at all. Their full social value is 'difficult to quantify." ${ }^{96}$ Moreover, in encouraging these uses by leaving them in the public domain, copyright law rightly pursues goals and expresses values that are other than economic. Frischmann claims that ' $\mathrm{r}$ ] framing copyright in this manner helps bridge the gap between economic and 'noneconomic' theories of intellectual property and begins to lay the foundation for a different way of conceptualizing and evolving copyright law. ${ }^{97}$ But does it? Ultimately Frischmann offers no theory of the 'noneconomic' dimension of copyright, and gives no account of the 'ancillary social value' the production of which copyright is supposed to encourage except the lame assertion that this ancillary value is 'well recognised as reflected in our society's long-standing normative commitments. ${ }^{9}$ Indeed in the end, having hinted at the limits of economics, he simply reverts to the claim that 'there are strong economic reasons to question the Demsetzian impulse in copyright law' and that a limited, 'leaky' copyright system 'can be an attractive and viable allocation system for nonrival resources, such as intellectual resources, provided that we can overcome supply-side problems and create sufficient incentives to provide the resources in the first place. ${ }^{9} 9$

It is tempting to conclude this discussion with the suggestion that the only normative thesis that can be attributed to Harold Demsetz is one that Mark Lemley and Brett Frischmann in fact share, and indeed must share if they are to remain - as they claim - committed to an economic analysis of copyright in some form. Essentially, either they are doing economic analysis - in which case everything they want to say about the proper design of the copyright system must

\footnotetext{
93 Frischmann, n 14 above, 670.

94 ibid, 664.

95 This indeed is Sag's interpretation of Frischmann's argument: see n 24 above, 211-212.

96 Frischmann, n 14 above, 670.

97 ibid, 672 .

98 ibid, 670

99 ibid, 673.
} 
be said in terms consistent with the logic of economic analysis ${ }^{100}$ - or they are not, in which case their argument rests on a different foundation which they neither fully reveal nor appropriately justify. Yet they try both to do economic analysis and not do it at the same time, on the ground that its limitations need to be cured by adding a supplement drawn from elsewhere - 'our society's long-standing normative commitments' (or some undisclosed 'nonutilitarian first principle' to which they are personally committed). Unfortunately, this attempt to think economic analysis together with some other (inadequately elaborated) framework which is radically at odds with economic analysis ends only in contradiction.

\section{CONCLUSION}

In the end, then, it is hard to be persuaded that Lemley's and Frischmann's critique(s) of the absolute protection paradigm could have much critical purchase on the paradigm. Their shared difficulty lies in their unwillingness to leave lawand-economics behind when taking on the latter's most bullish representative in the field of copyright - neoclassical property rights theory - and their consequent inability to offer a comprehensive analysis of the social significance of copyright law, and in particular its infringement norms. This in turn, I suggest in conclusion, is bound up with their failure to produce a satisfactory account of copyright law's relation to what Jürgen Habermas calls the 'lifeworld'101 - the web of intersubjectively-produced interpretive, evaluative and expressive frameworks that both enable what we experience as facts, norms and personal identities and make it possible to renew or to question these. ${ }^{102}$ From the perspective advanced by

\footnotetext{
100 In a telling rejoinder to Frischmann's critique of this theory, Demsetz has recently rebuked Frischmann for failing to recognise this. Demsetz insists that persistent externalities can always be recharacterised as products of the market, not as indicators of the market's limits (n 58 above 132). Equally, the social demand understated by consumers' willingness to pay can be re-characterised as a set of private demands awaiting market representation once the benefit of this exceeds the cost (ibid). Finally, Demsetz regards it as simply meaningless to say that there is something called a societal benefit or cost that is separable from private benefits and costs without relinquishing the fundamental premise of modern economics, which is that 'social cost and social benefit are, respectively, summations of privately borne cost benefits [sid]' (ibid).

101 Jürgen Habermas, The Theory of Communicative Action vol 2 (Cambridge: Polity Press, 1987). Very briefly, Habermas represents modern society as constituted by two distinct spheres - 'lifeworld' and 'system' each of which exemplifies a different form of rationality (communicative and instrumental-strategic rationality respectively). For Habermas, the lifeworld has priority over the system (which comprises the subsystems of state-administration and economy): the system is embedded in and indeed parasitic on the lifeworld (ibid, 154). Yet the lifeworld is threatened by the seemingly inexorable encroachments of the system, and law is implicated in this process of 'colonisation.'

${ }^{102}$ Habermas claims that modern subjects are capable of recognising three distinct 'worlds' constituting their lifeworld - an objective world of facts, a social world of norm-guided interactions and a subjective world of inner experience. Corresponding to these worlds are three distinct criteria of 'validity' - truth, rightness, and authenticity - by reference to which cognitive, normative and expressive utterances are rendered rationally acceptable to others. By contrast, economic theory posits purposively acting, selfcontained agents who only relate to one world - an objectively existing state of affairs. It cannot therefore grasp the complexity of modern action orientations.
} 
Lemley and Frischmann, the lifeworld is invisible except as an environment for economic activity. Moreover, the collectively-generated meanings it enables appear, from this perspective, as an undifferentiated collection of individuallyproduced 'information resources', distinguishable from society's tangible resources only in that it is relatively difficult to subject them to the price mechanism. Other equally reductive representations of the activities regulated by copyright law are linked with this one. The reasons motivating efforts to renew or alter the lifeworld's collectively-generated meanings in the process of producing or engaging with copyright works (eg concerns to advance knowledge in a particular field, to promote more legitimate political arrangements, or to achieve authentic self-expression) are reduced to nothing other than exogenous individual 'preferences'. Social consequences of these efforts that are not registered by the market (eg scientific progress, a more vibrant public sphere) are reduced to 'spillover' effects of individuals' purposively-rational decisions. The symbolic reproduction of society is reduced to a mere by-product of its material reproduction. And as a consequence of these representations of copyright law's domain, copyright law itself is reduced to nothing more than a 'medium' in Habermas's sense of that term. ${ }^{103}$

Considered in relation to the increasing complexity of the modern economic 'system' (in Habermas's sense), copyright law's evolution has indeed been organised around the function of augmenting the support available for marketised production, distribution and consumption of 'information.' But considered in relation to the lifeworld, copyright law also reflects intersubjectively shared values - notably freedom of expression, the autonomy of art, access to knowledge and equal participation in the process of cultural transmission. These values are given a binding form in what Lemley and Frischmann refer to as the 'commons' aspects of copyright law (e.g. its defences and exceptions), but also in, for example, its provision for authors' moral rights and (where these exist) its mechanisms for compensating authors for their unequal bargaining power relative to commercial investors. Such doctrines - which together form a regime of cultural rights within copyright law - reflect norms that are legal 'institutions' in Habermas's sense. Together, they have helped to defend the lifeworld against the encroachments of the system - the very encroachments that copyright law in its guise of medium has itself encouraged - by facilitating the discussion and critique of the products of the culture industry. Yet this defence does not depend purely on legal institutions. It

\footnotetext{
103 In The Theory of Communicative Action Habermas theorises law as simultaneously a 'steering medium' constituting the subsystems of administration and economy and (along with the media of power and money) directing their development - and an 'institution', reflecting and giving binding force to norms developed informally in the lifeworld. Hence law is both a medium of the lifeworld's 'colonisation' and a mechanism for its defence and invigoration (ibid, 356-373). (Habermas's conception of what is entailed by law's existence as a 'medium' admittedly shifts somewhat in his subsequent work, notably Between Facts and Norms (Cambridge: Polity 1996), but there is no necessary inconsistency between his later position and the argument developed in The Theory of Communicative Action). In The Theory of Communicative Action at least, Habermas characterises new social movements - not courts or legislatures - as the real engines of resistance to colonisation and the most effective laboratories for the development of new institutions that could contain this threat.
} 
also depends on practices of resistance to system encroachments: indeed informally recognised norms can become legally institutionalised only to the extent that these practices mobilise decisions within the political system that have legal force. Copyright law is more vulnerable to resistance than most legal regimes: infringements are relatively difficult to police and effective policing inevitably conflicts with well-established expectations of privacy and personal freedom. Hence even where copyright law has categorised activities as unlawful - such as photocopying entire books for personal study or uploading others' music to social networking websites in acts of self-expression - these prohibitions have been widely flouted, and without attracting moral condemnation. ${ }^{104}$

Law-and-economics cannot account for these doctrines and practices except via an impoverished language of 'commons' and 'free-riding' that wholly misses their point. Far from diagnosing and curing this deficiency, Lemley's and Frischmann's criticisms of the absolute protection paradigm simply exemplify it. The only way out of the impasse towards which their approach leads, it seems to me, is to contest the implicit claim of economic theory to be a comprehensive theory of society and rational action. Hence (although space does not permit this project to be advanced very far here) I end this paper by proposing Jürgen Habermas's social theory as an alternative framework in relation to which critics of copyright expansionism might fruitfully orient ourselves in the future. This is for four main reasons. First, Habermas's two-tiered conception of modern society as constituted by the distinct spheres of system and lifeworld yields a rigorous conceptualisation of the tension between the economic and the non-economic realms - a tension that Lemley and Frischmann hint at but cannot adequately explain. Second, Habermas's distinction between law as medium and as institution better accounts for these commentators' own intuitions about copyright law: that it both serves an economic function (in underpinning investments) and preserves non-economic values (eg in enabling critical debate). Third, Habermas's evolutionary conception of society - his understanding of society as subject to historical change, and his conviction that there is a logic to that process of change - illuminates the historicity of copyright law (and law in general) in interesting ways. In particular, it explains both the possibility and the necessity of seeing copyright expansionism - and the resistances to it - in the context of broader societal tendencies, not as discrete phenomena that could be evaluated in relation to an idea of 'the market' as an unquestionable given of social life. Fourth, this evolutionary conception of society affords a new perspective on contemporary practices of copyright infringement: it brings these practices into view as aspects of a diffuse social movement to defend the lifeworld against an historical process - the 'colonisation' of the lifeworld by the system - that Habermas (plausibly, it seems to me) regards as pathological. In other words, Habermas's social theory enables us to take seriously the possibility that, in some instances at least,

104 See generally John Tehranian, 'Infringement Nation: Copyright Reform and the Law/Norm Gap' (2007) 3 Utab Law Review 537. 
copyright infringement is not just unlawful behaviour, or a form of 'free-riding' on the investments of others; rather, it may be oriented towards reclaiming processes of cultural transmission, social integration and socialisation from the systemic logic to which intellectual property law (amongst other forces) subjects them, and so serve to advance social emancipation.

I am far from suggesting here that every aspect of copyright law and the domain that it regulates could be adequately explained in Habermasian terms, not least because the blind spots within Habermas's own conceptions of society ${ }^{105}$ and rational action ${ }^{106}$ are problematic in their turn. What I am suggesting is that the hegemony of economic analysis within scholarly commentary on copyright law can only be effectively challenged from the perspective of a critical theory of society; and that Habermas's version of critical theory seems a particularly illuminating basis from which to address the very concern that Mark Lemley and Brett Frischmann espouse - to counteract the threat to society represented by relentlessly spreading commodification processes, including copyright expansionism.

\footnotetext{
${ }^{105}$ For example, Axel Honneth (Critique of Power (Cambridge, MA: MIT Press 1991)) argues persuasively that Habermas hypostatises the system as an arena of 'norm-free sociality' and the lifeworld as an arena of 'power-free communication.'

106 See eg Pieter Duvenage, Habermas and Aesthetics (Cambridge: Polity, 2003); Nikolas Kompridis, Critique and Disclosure (Cambridge, MA: MIT Press 2006).
} 